sức khỏe cán bô tỉnh Bắc Giang năm 20122016", số lượt xét nghiệm năm 2015 (tăng hơn năm 2014 là 8,76\%) năm 2016 (tăng hơn 2015 là 19\%) (3). Tất cả các cận lâm sàng đều tăng nhưng chỉ có dịch vụ Xquang và CT-Scan tại 02 phòng khám tăng trong năm 2018 và giảm trong năm 2019. Số lượng Xquang và CT-Scan giảm là do hệ thống Xquang của phòng khám gặp vấn đề tại đèn chụp, nguyên nhân nữa là cơ quan giám định BHXH không thanh toán một số các chỉ định Xquang và CT-Scan không có bệnh lý do đó phòng khám cũng hạn chế chụp đối với những chỉ định sàng lọc không cần thiết, phải có bệnh lý mới thực hiện chụp nên phòng khám hạn chế chụp Xquang và CT-Scan.

Khả năng cung cấp các dịch vụ kỹ thuật PKĐK Linh Xuân và Linh Tây. Số lượng DMKT của PKĐK Linh Xuân (1.194 kỹ thuật, tỷ lệ thực hiện được là $72 \%$ ) và PKĐK Linh Tây (561 kỹ thuâat, tỳ lệ thực hiên được là $63,2 \%$ ). Tỷ lê DMKT được duyệt của cả 02 phòng khám thấp hơn nhiều so với danh mục được duyệt tại Phòng khám đa khoa Khu vực Tân Bình, Huyện Thanh Bình, Tỉnh Đồng Tháp năm 2015" là 3.669 kỹ thuật (5). Số lượng danh mục được triển khai tại 2 phòng khám được đánh giá về mặt hiệu quả thông qua số lượng phẫu thuật, thủ thuật thực hiện. Số lượng phẩu thuật, thủ thuật tại phòng khám tăng theo từng năm, trong đó chủ yếu số lượng thủ luật loại 2 , loại 3 chiếm $96,5 \%$, số lượng phẫu thuật chiếm tỷ lệ thấp dưới $1 \%$ (chỉ có PKĐK Linh Xuân thực hiện).

\section{KẾT LUẬN}

Kết quả nghiên cứu cho thấy tổng số lượng nhân viên y tế công tác tại cả 2 phòng khám đều tăng theo từng năm, tuy nhiên số lượng nhân sự có trình độ sau đại học còn thấp, thiếu bác sĩ chuyên khoa. Tổng số lượt khám chữa bệnh của 02 phòng khám ngày càng tăng, trong đó số lượt khám BHYT là chủ yếu, chiếm tới hơn $90 \%$. Số lượng khám chữa bệnh tại 02 phòng khám chủ yếu là chuyên khoa nội (chiếm trên $50 \%$ ), số lượng khám chữa bệnh chuyên khoa lẻ như răng hàm mặt, tai mũi họng, da liễu, mắt còn thấp. Tất cả các cận lâm sàng đều tăng nhưng chỉ có dịch vụ Xquang tại 02 phòng khám tăng trong năm 2018 và giảm trong năm 2019. Danh mục kỹ thuật được duyệt còn thấp.

Kiến nghị: Tuyển thêm nhân sự chuyên khoa đặc biệt là các bác sĩ, tạo điều kiện cho các bác sĩ đi học các lớp sau đại học để nâng cao trình độ chuyên môn, đề xuất xin duyệt thêm danh mục kỹ thuật, sửa chữa hoặc đâu tư nâng cấp hệ thống chụp Xquang.

TÀI LIẸU THAM KHẢO

1. Sở Y tế (2019). "Báo cáo thống kê y tế TP.Hồ Chí Minh năm 2018".

2. Sở Y tế (2020). "Báo cáo thống kê y tế TP.Hồ Chí Minh năm 2019".

3. Vũ Thanh Gianq (2017). "Thức trana cuna cấp dich vu chăm sóc sức khỏe tai phòna khám thuôc Ban bảo vê. chăm sóc sức khỏe cán bô tỉnh Bắc Giana aiai đoan năm 2012 đến 2016". Chuvên khoa 2 quản lý y tế, Trường Đại học $Y$ tế công côna Hà Nôi.

4. Đố Thu Hườna (2019). "Chất lươna dich vu khám, chữa bênh và môt số vếu tố ảnh hưởna tai khoa Khám bênh đa khoa Viên Y dước hoc dân tôc Thành phố Hồ Chí Minh năm 2019", Trường đại hoc $Y$ tế cônq cônq Hà Nôi.

5. Châu Văn Mṽ (2015). "Thức trana cuna cấp dich vu khám chữa bênh tai PKĐKKV Tân Bình, Huvên Thanh Bình, Tỉnh Đồnq Tháp năm 2015", Trường Đai hoc Y tế côna côna Hà Nôi.

6. Ouốc Hôi (2014). "Luât sửa đổi, bổ sung một số điều của Luật Bảo hiểm y tế".

\title{
NGHIÊN CỨU MỐI TƯƠNG QUAN GIỮA TẢI LƯỢNG HBV DNA VÀ HOẠT Độ ENZYM ALT Ở BỆNH NHÂN VIÊM GAN VI RÚT B MẠN TÍNH
}

\section{TÓM TẮT}

Muc tiêu: Khảo sát tải lương HBV-DNA, hoat độ ALT huyết thanh và bước đầu đánh giá mối tương quan giữa tải lượng HBV DNA với hoạt độ enzym ALT

${ }^{1}$ Bệnh viện Quân y 103

2Ban khoa hoc quân sự, Bênh viên Quân y 103

Chịu trách nhiệm chínhi: Lế Văn Nam

Email: drlenam103@gmail.com

Ngày nhận bài: 4.01 .2021

Ngày phản biên khoa hoc: 2.3.2021

Ngày duyệt bài: 12.3.2021

\section{Lê Văn Nam¹, Đỗ Như Bình ${ }^{2}$}

ở bệnh nhân viêm gan vi rút $\mathrm{B}$ mạn tính (VGBMT). Đối tượng và phương pháp nghiên cứu: Nghiên cứu mô tả cắt ngang, hối cứu trên 39 bệnh nhân viêm gan $B$ mạn tính điều trị tại khoa Truyền nhiễm Bệnh viện Quân y 103 từ 03/2018 đến 04/2019. Kết quả: Tải lượng HBV DNA trung bình của nhóm bệnh nhân nghiên cứu là $1,2 \times 10^{8} \pm 0,7 \times 10^{7}$ copies $/ \mathrm{mL}$. Hoạt độ ALT huyết thanh trung bình của các bênh nhần nghiên cứu là $561,94 \pm 207,19$ U/L. Chưa có mối tương quan có ý nghĩa thống kê nào giữa giữa tải lượng HBV DNA huyết thanh với hoạt độ ALT huyết thanh ở các bệnh nhân VGBMT nói chung ( $r=-0,12$; $p=0,46)$ cũng như từng nhóm bệnh nhân nói riêng. 
Kết luận: Tải lượng HBV DNA trung bình là $1,2 \times 10^{8}$ $\pm 0,7 \times 10^{7}$ copies $/ \mathrm{mL}$. Hoat độ ALT huyết thanh trung bình là 561,94 \pm 207,19 U/L. Không có mối tương quan có ý nghĩa thống kê nào giữa giữa tải lượng HBV DNA huyết thanh với hoạt độ ALT huyết thanh ở các bênh nhân VGBMT.

Tư khoá: Viêm gan vi rút $B, H B V-D N A$, alanine aminotransferase.

\section{SUMMARY \\ CORRELATION BETWEEN SERUM HBV DNA LEVEL AND ALT ACTIVITY IN CHRONIC HEPATITIS B PATIENTS}

Objectives: To investigate HBV-DNA load, serum alanine aminotransferase activity and assess the correlation between HBV-DNA load and serum alanine aminotransferase activity in patients with chronic hepatitis B. Methods: It was a cross-sectional, retrospective study which included 39 patients with chronic hepatitis B patients at Department of Infectious Diseases, Military Hospital 103 from March 2018 to April 2019. Results: The average serum load of HBV-DNA was $1.2 \times 10^{8} \pm 0.7 \times 10^{7}$ copies $/ \mathrm{mL}$. The average activity of serum ALT was $561.94 \pm 207.19$ $\mathrm{U} / \mathrm{L}$. There were no significant correlations between serum HBV-DNA load and serum ALT in patients with chronic hepatitis $B((r=-0.12 ; p=0.46)$ and in subgroups of patients. Conclusion: The average serum load of HBV-DNA was $1.2 \times 10^{8} \pm 0.7 \times 10^{7}$ copies $/ \mathrm{mL}$. The average activity of serum ALT was $561.94 \pm 207.19 \mathrm{U} / \mathrm{L}$. There were no significant correlations between serum HBV-DNA load and serum ALT in patients with chronic hepatitis $B$.

Keywords: chronic hepatitis B, HBV-DNA, alanine aminotransferase.

\section{I. ĐĂT VẤN ĐỀ}

Theo thống kê của Tổ chức $Y$ tế Thế giới, có khoảng 2 tỷ người nhiễm vi rút viêm gan $B$ (Hepatitis B virus - HBV), trong đó 350 triệu người mang vi rút mạn tính [8]. Hàng năm, ước tính có khoảng 2 triệu người mang vi rút viêm gan $B$ mạn tính chết vì xơ gan và ung thư gan trên thế giới. Viêt Nam nằm trong khu vực có nguy cơ cao về nhiễm HBV và là một trong những nước có tỷ lệ bệnh lưu hành cao nhất thế giới, tỷ lệ người mang HBV trung bình là $15-25 \%$ [2].

Hiên nay, với viêc sử dung các thuốc kháng vi rút đồng đẳng nucleot(s)ise (NA - nucleot(s)ise analog) và interferon (IFN) đã cho thấy hiệu quả giảm nhanh tải lượng HBV DNA huyết thanh, giảm nồng độ ALT (alanine transaminase) huyết thanh và cải thiện tổn thương gan trên mô bệnh học. Nhờ đó, theo dõi tải lượng HBV DNA huyết thanh đã được ứng dụng rộng rãi trong theo dõi điều trị ở bệnh nhân viêm gan vi rút $B$ mạn tính (VGBMT). Bởi vậy, chúng tôi thực hiện đề tài "Nghiên cứu mối tương quan giữa tải lượng HBV DNA và hoạt độ enzym ALT ở bênh nhân viêm gan vi rút $B$ mạn tính" với 2 mục tiêu:
1. Khảo sát tải lượng HBV -DNA và hoạt đô $A L T$ huyêt thanh ở bệnh nhân viêm gan vi rút $B$ man tính.

2. Bước đầu đánh giá mối tương quan giữa tải lượng HBV DNA và hoat độ enzym ALT ở bệnh nhân viêm gan vi rút B mạn tính.

\section{II. ĐỐI TƯỢNG VÀ PHƯƠNG PHÁP NGHIÊN CỨU}

1. Đối tượng nghiên cứu. Nghiên cứu được thực hiện trên 39 bệnh nhân viêm gan $B$ mạn tính điều trị tại khoa Truyền nhiễm Bệnh viện Quân y 103 từ 03/2018 đến 04/2019.

* Tiêu chuẩn lựa chọn bệnh nhân

- HBsAg (+) > 6 tháng hoặc $\operatorname{HBsAg}(+)$ và antiHBc IgG (+).

- ALT/AST tăng liên tục hay từng đợt.

* Tiêu chuẩn loai trừ

- Đồng nhiễm vi rút viêm gan khác hoăc HIV. Bệnh nhân có tổn thương gan do nguyên nhân khác (rượu, thuốc, hóa chất, bệnh gan tự miễn...).

- Bênh nhân xơ gan do vi rút $B$.

- Bệnh nhân không đồng ý tham gia nghiên cứu.

2. Phương pháp nghiên cứu. Nghiên cứu mô tả cắt ngang, hồi cứu, chọn mẫu thuận tiện.

Toàn bộ bệnh án nghiên cứu được đăng ký theo một mẫu biểu thống nhất. Dữ liệu thu thập bao gồm các thông tin lâm sàng và kết quả xét nghiệm của bệnh nhân.

\section{Dữ liệu lâm sàng}

- Tất cả bệnh nhân vào viện sẽ được khai thác tiền sử, bệnh sử và khám lâm sàng để thu thập các thông tin sau:

+ Tuổi: Chia 2 nhóm dựa theo hướng dẫn của AASLD 2009: <40 tuổi và $\geq 40$ tuổi. Trong mỗi nhóm, chúng tôi lại chia thành các nhóm nhỏ hơn: $<30$ tuổi, 30-<40 tuổi, 40-<50 tuổi, $50-<60$ tuổi và $\geq 60$ tuổi.

+ Giới: nam và nữ.

+ Tiền sử: có bằng chứng nhiễm HBV trên 6 tháng hoặc bị viêm gan do vi rút $B$ trên 6 tháng.

+ Yếu tố dịch tễ: bản thân (truyền máu, phầu thuật, thủ thuật, xăm hình, quan hệ tình dục không an toàn) và gia đình.

+ Các triệu chứng lâm sàng: mệt mỏi, chán ăn, đau hạ sườn phải, vàng mắt, vàng da, tiểu vàng đậm, gan to, sao mạch, cổ trướng...

\section{Dữ liệu cận lâm sàng}

- Các xét nghiệm vi sinh: HBsAg, HBeAg, antiHBe, đinh lương HBV DNA.

- Xét nghiệm ALT huyết thanh và các xét nghiệm liên quan khác.

số liệu nghiên cứu được phân tích thống kê, sử dụng phần mềm SPSS 25. 
III. KẾT QUẢ NGHIÊN CỨU VÀ BÀN LUÂN

1. Đặc điểm của đối tượng nghiên cứu

Bảng 1: Đặc điểm về giới tính của bệnh nhân nghiên cứu

\begin{tabular}{|c|c|c|}
\hline Giới & $\mathbf{n}$ & $\mathbf{\%}$ \\
\hline Nam (\%) & 36 & 92,31 \\
\hline Nữ (\%) & 3 & 7,69 \\
\hline Tống & 39 & 100 \\
\hline
\end{tabular}

Về đặc điểm giới tính, nghiên cứu của chúng tôi ghi nhận tỷ lệ nam cao hơn nữ với tỷ lệ nam là $92,31 \%$ ở bệnh nhân VGBMT. Điều này phù hợp với nhận xét chung của nhiều tác giả về viêm gan $B$ tại Việt Nam đều cho rằng nam thường mắc cao hớn nữ giới ở các bệnh nhân nhiễm HBV. Nghiên cứu của của Ngô Viết Lộc (2012) ghi nhận tỷ lệ nam giới nhiễm HBV cao hơn có ý nghĩa so với nữ giới $(21,4 \%$ so với $12,05 \% ; p<0,05)$ [5], của Nguyến Đức Cường và Đỗ Quốc Tiệp (2017) thấy tỷ lệ HBsAg (+) ở nam giới là $15,99 \%$, cao hơn có ý nghĩa so với ở nữ giới là 9,65\% [2].

Bảng 2: Đặc điểm về tuổi của bệnh nhân nghiên cứu

2. Tải lượng HBV-DNA và hoạt độ ALT huyết thanh ở bệnh nhân viêm gan vi rút $B$ mạn tính

Bảng 3: Hoạt độ enzym ALT' và tải lượng HBV DNA ở nhóm bệnh nhân nghiên cứu

\begin{tabular}{|c|c|c|c|c|c|}
\hline & $\mathbf{n}$ & Min & Max & Mean & SD \\
\hline ALT (U/L) & 39 & 55,4 & 2547 & 561,94 & 207,19 \\
\hline HBV DNA (copies/mL) & 39 & 140 & $1,5.10^{9}$ & $1,2.10^{8}$ & $0,7.10^{8}$ \\
\hline
\end{tabular}

Bảng 4: Ngưỡng phát hiện HBV DNA ở các bệnh nhân VGBMT

\begin{tabular}{|c|c|c|c|}
\hline \multirow{2}{*}{} & \multicolumn{3}{|c|}{ Tải lương HBV DNA } \\
\cline { 2 - 4 } & $<\mathbf{3 0 0}$ & $\mathbf{2} \mathbf{3 0 0}$ & Tống \\
\hline $\mathrm{HBeAg}(+) /$ anti $\mathrm{HBe}(+)$ & 0 & 5 & 5 \\
\hline $\mathrm{HBeAg}(+) /$ anti $\mathrm{HBe}(-)$ & 0 & 13 & 13 \\
\hline $\mathrm{HBeAg}(-)$ /anti $\mathrm{HBe}(+)$ & 1 & 18 & 19 \\
\hline $\mathrm{HBeAg}(-)$ /anti $\mathrm{HBe}(-)$ & 0 & 2 & 2 \\
\hline
\end{tabular}

Trong nghiên cứu này, hoạt độ ALT huyết thanh trung bình của các bệnh nhân nghiên cứu là $561,94 \pm 207,19 \mathrm{U} / \mathrm{L}$. Kết quả này cho thây tình trạng enzym gan tăng rất cao và đang có tình trạng phá hủy tế bào gan mạnh. Bên cạnh đó, tải lượng HBV DNA trung bình là $1,2 \times 10^{8} \pm$ $0,7 \times 10^{8}$ copies/mL (cao nhất là $1,5 \times 10^{9}$ và thấp nhất là 140). Trong số 39 bệnh nhân được nghiên cứu thì chỉ có 1 bệnh nhẩn có tải lượng HBV DNA < 300 copies/mL còn lại tất cả bệnh nhân khác đều có tải lượng HBV DNA cao trên 300 copies/mL, biểu hiện tình trạng sao chép của vi rút đang diễn ra.

3. Mối tương quan giữa tải lượng $\mathrm{HBV}$ DNA với tuổi, giới và hoạt độ enzym ALT ở bệnh nhân viêm gan vi rút $B$ mạn tính

\begin{tabular}{|c|c|c|c|}
\hline \multicolumn{2}{|c|}{ Độ tuối } & \multicolumn{2}{|c|}{$\mathbf{n}(\%)$} \\
\hline \multirow{2}{*}{$\begin{array}{l}< \\
40\end{array}$} & $<30$ & \multirow{2}{*}{$\begin{array}{c}26 \\
(66,67 \%)\end{array}$} & $7(17,94 \%)$ \\
\hline & $30-39$ & & $19(48,74 \%)$ \\
\hline \multirow{3}{*}{$\begin{array}{l}\geq \\
40\end{array}$} & $40-49$ & \multirow{3}{*}{$\begin{array}{c}13 \\
(33,33 \%)\end{array}$} & $5(12,82 \%)$ \\
\hline & $50-59$ & & $4(10,25 \%)$ \\
\hline & $\geq 60$ & & $4(10,25 \%)$ \\
\hline \multicolumn{2}{|c|}{$\begin{array}{l}\text { Mean } \pm \text { SD } \\
\text { Min-Max }\end{array}$} & \multicolumn{2}{|c|}{$\begin{array}{l}39,43 \pm 12,58 \\
(21-73)\end{array}$} \\
\hline
\end{tabular}

Về phân bố bệnh nhân theo nhóm tuối, nghiên cứu của chúng tôi cho thây độ tuổi trung bình của bênh nhân VGBMT là $39,43 \pm 12,58$ tuổi, gặp nhiều ở nhóm tuổi 30-39 tuổi (48,74\% số bệnh nhân). Đặc điểm này cũng tương tự kết quả của các nghiên cứu trong nước. Ớ bệnh nhân VGBMT, kết quả nghiên cứu của Nguyễn Văn Dũng (2015) cho thấy tuổi trung bình của bệnh nhân VGBMT là 39,6 \pm 13,9 tuổi, trong đó Nghiên cứu của Đình Văn Huy (2012) nhận thấy bệnh nhân VGBMT có độ tuổi trung bình là 38,2 \pm 10,9 tuổi, gặp nhiều nhất ở lứa tuổi 31 - 40 (35,8\%) [4], của Nguyễn Hữu Quyền (2015) thấy bênh nhân VGBMT găp chủ yếu ở hai nhóm tuổi $21-30$ và $31-40$ tuổi (33,3\% và 30,4\%) [7]. bệnh nhân <40 tuổi chiếm tỷ lệ 52,5\% [3].

Bang 5: Mối liên quan giứa tải lương HBV DNA với tuôii, giới và hoạt độ enzym ALT ở nhóm bệnh nhân nghiên cứu.

\begin{tabular}{|c|c|c|c|}
\hline & \multicolumn{2}{|c|}{$\begin{array}{l}\text { Tải lượng HBV DNA } \\
\text { (Copies/mL) }\end{array}$} & \multirow[b]{2}{*}{ p } \\
\hline & $<300$ & $\geq \mathbf{3 0 0}$ & \\
\hline $\operatorname{Nam}(n=36)$ & 1 & 35 & \\
\hline$N \tilde{u}^{\prime}(\mathrm{n}=3)$ & 0 & 3 & $>0,05$ \\
\hline Tuổi $(n=39)$ & 32 & $39,63 \pm 12,69$ & $<0,05$ \\
\hline $\operatorname{ALT}(n=39)$ & 150 & $572,78 \pm 180,9$ & $<0,05$ \\
\hline
\end{tabular}

$\mathrm{cp} / \mathrm{mL}$, tuổi trung bình và hoạt độ trung bình ALT đều cao hơn có ý nghĩa so với nhóm bệnh nhân có HBV DNA $<300 \mathrm{cp} / \mathrm{mL}$. Điều này cũ̃ng phù hợp với diễn tiến tự nhiên của nhiễm HBV. Với nhóm bệnh nhân có HBV DNA $\geq 300$ copies/mL, hoạt động sao chép của vi rút đang diên ra, trong giai đoạn thải trừ miễn dịch có tổn thương phá hủy tế bào gan gây tăng enzym gan. Còn với nhóm bệnh nhân có tải lượng HBV DNA < 300 copies/mL, hoạt động sao chép của vi rút không diển ra, tốn thương mô bệnh học gan và enzym gan giảm. 


\begin{tabular}{|c|c|c|c|c|c|c|}
\hline \multirow{3}{*}{\multicolumn{2}{|c|}{ Đặc điểm }} & \multicolumn{4}{|c|}{ Nhóm } & \multirow{3}{*}{$\mathbf{p}$} \\
\hline & & $\begin{array}{l}\text { HBeAg(+)/ } \\
\text { antiHBe }(+)\end{array}$ & $\begin{array}{l}\text { HBeAg(+)/ } \\
\text { antiHBe (-) }\end{array}$ & $\begin{array}{c}\text { HBeAg(-)/ } \\
\text { antiHBe (+) }\end{array}$ & $\begin{array}{l}\text { HBeAg(-)/ } \\
\text { antiHBe (-) }\end{array}$ & \\
\hline & & I & II & III & IV & \\
\hline \multirow{2}{*}{\multicolumn{2}{|c|}{\begin{tabular}{|c|}
$n$ \\
Giới (Nam/ Nữ)
\end{tabular}}} & 5 & 13 & 19 & 2 & \\
\hline & & $5 / 0$ & $13 / 0$ & $16 / 3$ & $2 / 0$ & \\
\hline \multicolumn{2}{|c|}{$\begin{array}{c}\text { Tuổi } \\
\text { (min-max) }\end{array}$} & $\begin{array}{c}29,20 \pm 5,16 \\
(25-37)\end{array}$ & $\begin{array}{c}35,76 \pm 9,55 \\
(22-60)\end{array}$ & $\begin{array}{c}44,89 \pm \\
14,07 \\
(21-73)\end{array}$ & $\begin{array}{c}37,5 \pm 0,7 \\
(37-38)\end{array}$ & $\begin{aligned} \mathrm{p}_{\mathrm{I}, \mathrm{II}} & =0,16 \\
\mathbf{p}_{\mathrm{I}, \mathrm{III}} & =\mathbf{0 , 0 2} \\
\mathrm{p}_{\mathrm{I}, \mathrm{IV}} & =0,08 \\
\mathrm{p}_{\mathrm{II}, \mathrm{III}} & =0,051 \\
\mathrm{p}_{\mathrm{II}, \mathrm{IV}} & =0,8 \\
\mathrm{p}_{\mathrm{III}, \mathrm{IV}} & =0,47\end{aligned}$ \\
\hline \multicolumn{2}{|c|}{$\begin{array}{l}\text { HBV DNA } \\
(X \pm S D) \\
(\min -\mathbf{m a x})\end{array}$} & $\begin{array}{c}3,6 \times 10^{7} \pm \\
0,7 \times 10^{7}\end{array}$ & $\begin{array}{c}3,1 \times 10^{8} \pm \\
1,2 \times 10^{8}\end{array}$ & $\begin{array}{c}2,9 \times 10^{7} \pm \\
0,4 \times 10^{7}\end{array}$ & $\begin{array}{c}6,7 \times 10^{6} \pm \\
4,5 \times 10^{6}\end{array}$ & $\begin{aligned} \mathrm{p}_{\mathrm{I}, \mathrm{II}} & =0,18 \\
\mathrm{p}_{\mathrm{I}, \mathrm{III}} & =0,76 \\
\mathrm{p}_{\mathrm{I}, \mathrm{IV}} & =0,62 \\
\mathbf{p}_{\mathrm{II}, \mathrm{III}} & =\mathbf{0}, \mathbf{0 3} \\
\mathrm{p}_{\mathrm{III}, \mathrm{IV}} & =0,34\end{aligned}$ \\
\hline ALT & $\begin{array}{c}X \pm S D \\
(\min - \\
\max )\end{array}$ & $\begin{array}{c}1070,66 \pm \\
920,70 \\
(293,3- \\
2547)\end{array}$ & $\begin{array}{c}456,5 \pm \\
274,78 \\
(104,8- \\
1640,81)\end{array}$ & $\begin{array}{c}494,84 \pm \\
273,86 \\
(55,4- \\
1851,15)\end{array}$ & $\begin{array}{c}612,95 \pm \\
465,34 \\
(283,9- \\
942)\end{array}$ & $\begin{array}{l}\mathrm{p}_{\mathrm{I}, \mathrm{II}}=0,25 \\
\mathrm{p}_{\mathrm{I}, \mathrm{III}}=0,28 \\
\mathrm{p}_{\mathrm{I}, \mathrm{IV}}=0,58 \\
\mathrm{p}_{\mathrm{IIIII}}=0,82 \\
\mathrm{p}_{\mathrm{IIIV}}=0,67 \\
\mathrm{p}_{\mathrm{III}, \mathrm{IV}}=0,74 \\
\end{array}$ \\
\hline \multirow{2}{*}{\multicolumn{2}{|c|}{$\begin{array}{l}\text { Tương quan } \\
\text { giữa ALT và } \\
\text { HBV DNA }\end{array}$}} & $\begin{array}{l}r=-0,6 \\
p=0,28\end{array}$ & $\begin{array}{l}r=-0,04 \\
p=0,87\end{array}$ & $\begin{array}{l}r=0,18 \\
p=0,43\end{array}$ & $\begin{array}{c}r=-1 \\
p=0,31\end{array}$ & \\
\hline & & & $r=-0,12$ & $0=0,46$ & & \\
\hline
\end{tabular}

Trong nhóm bênh nhân nghiên cứu, độ tuổi của bệnh nhân VGVRBMT có HBeAg (+) nhìn chung thấp hơn độ tuổi của bệnh nhân có HBeAg (-). Trong đó độ tuổi của nhóm bênh nhân có $\mathrm{HBeAg}(+) / a n t i H B e(-)$ thấp hơn độ tuổi của nhóm bệnh nhân có HbeAg(-) /antiHBe $(+)$ có ý nghĩa thống kê $(p<0,05)$.

Tải lượng HBV DNA cao nhất ở nhóm bênh nhân $\mathrm{HBeAg}(+) /$ antiHBe(-)( nhóm II) (3,1. 108 $\left.\pm 1,2 \cdot 10^{8}\right)$. Tải lượng HBV DNA ở nhóm bệnh nhân $\mathrm{HBeAg}(-) /$ antiHBe(+) thấp hơn so với nhóm bệnh nhân $\mathrm{HBeAg}(+) /$ antiHBe(-), sự khác biệt này có ý nghĩa thống kê $(p<0,05)$. Kết quả của chúng tôi phù hợp với một số nghiên cứu trong nước và quốc tế. Nghiên cứu của Đình Văn Huy (2012) ghi nhận tải lượng HBV DNA huyết thanh trung bình ở nhóm bệnh nhân VGBMT, HBeAg $(+)(8,06 \pm 0,85$ log 10 copies $/ \mathrm{mL})$ cao hơn so với tải lượng HBV DNA huyết thanh trung bình $(6,27 \pm 1,26 \log 10$ copies $/ \mathrm{mL})$ ơ nhóm bệnh nhân có HBeAg (-). Sự khác biệt này có ý nghĩa thống kê với $p<0,05$ [4]. Tác giả Nguyễn Hữu Quyền (2015) nghiên cứu trên bệnh nhân VGBMT cũng ghi nhận tải lượng HBV DNA huyết thanh ở bệnh nhân có HBeAg $(+)$ cao hơn có ý nghĩa so với bệnh nhân có HBeAg (-) $(8,7 \pm 8,7$ $\log 10$ copies $/ \mathrm{mL}$ so với $7,2 \pm 7,5 \log 10$ copies $/ \mathrm{mL}, \mathrm{p}<0,05)$ [7]. Hoat độ ALT thấp nhất ở nhóm bệnh nhân $\mathrm{HBeAg}(+) /$ antiHBe(-), cao nhất ở nhóm bênh nhân $\mathrm{HBeAg}(+) /$ antiHBe $(+)$ $(1070,66 \pm 920,7)$, tuy nhiên sự khác biệt này không có ý nghĩa thống kê $(p>0,05)$.

Chưa có mối tương quan có ý nghĩa thống kê nào giữa giữa tải lượng HBV DNA huyết thanh với hoạt độ ALT huyết thanh ở các bệnh nhân VGBMT nói chung $(r=-0,12 ; p=0,46)$ cũng như từng nhóm bệnh nhân nói riêng. Nguyên nhân của hiên tượng không có sự tương quan giữa tải lượng HBV DNA huyết thanh với hoạt độ ALT huyết thanh ở bệnh nhân VGBMT nói chung có thể do cơ chế bệnh sinh của nhiễm HBV mạn tính, trong giai đoạn thanh thải miễn dịch (do đối tượng nghiên cứu trong nghiên cứu của chúng tôi chủ yếu là các bệnh nhân trong đợt bùng phát của VGBMT), có sự ức chế một phần quá trình nhân lên của vi rút, tuy nhiên tế bào gan lại bị hủy hoại do có sự tham gia của cơ chế miễn dịch với sự tham gia của tế bào giết tư nhiên, CD4+ hay $\mathrm{CD} 8+$ hoạt hóa bài tiết interferon gama và TNF alpha làm giảm sự nhân lên của HBV và trực tiếp ly giải tế bào gan bị nhiễm HBV do đó làm tăng hoạt độ ALT. 


\section{KẾT LUÂ̂N}

1. Tải lượng HBV DNA và hoạt độ ALT huyết thanh ở bệnh nhân VGBMT

- Tải lượng HBV DNA trung bình của nhóm bệnh nhân nghiên cứu là $1,2 \times 10^{8} \pm 0,7 \times 10^{7}$ copies $/ \mathrm{mL}$ (cao nhất là $1,5 \times 10^{9}$ copies $/ \mathrm{mL}$ và thấp nhất là 140 copies $/ \mathrm{mL}$ ). Trong đó tải lượng HBV DNA ở những bệnh nhân có $\mathrm{HBeAg}(+) /$ AntiHBe(-) là $3,1 \times 10^{8} \pm 1,2 \times 10^{8}$ cao hơn có ý nghĩa thống kê so với nhóm bệnh nhân $\mathrm{HBeAg}(-)$ /AntiHBe(+) là $2,9 \times 10^{7} \pm 0,4 \times 10^{7}$ (với $p<0,05$ )

- Hoạt độ ALT huyết thanh trung bình của các bệnh nhân nghiên cứu là 561,94 \pm 207,19 U/L. Khi so sánh hoat độ ALT huyết thanh trung bình của hai nhóm bệnh nhân có $\mathrm{HBV}$ DNA $\geq 300$ và $<300$ copies $/ \mathrm{mL}$, chúng tôi nhận thấy rằng hoạt độ ALT ở nhóm bệnh nhân HBV DNA $\geq 300$ copies/mL là $572,78 \pm 180,9 \mathrm{U} / \mathrm{L}$ cao hơn có ý nghĩa thống kê với nhóm bênh nhân có $\mathrm{HBV}$ DNA < 300 copies $/ \mathrm{mL}$ là $150 \mathrm{U} / \mathrm{L}$.

2. Mối tương quan giữa tải lượng $\mathrm{HBV}$ DNA và hoạt độ ALT huyết thanh ở bệnh nhân VGBMT. Trong nghiên cứu bước đầu của chúng tôi, chưa có mối tương quan có ý nghĩa thống kê nào giữa giữa tải lượng HBV DNA huyết thanh với hoạt độ ALT huyết thanh ở các bệnh nhân VGBMT nói chung $(r=-0,12 ; p=0,46)$ cũ̃ng như từng nhóm bệnh nhân nói riêng.

\section{TÀI LIÊU THAM KHẢO}

1. Đỗ Tuấn Anh (2012), "Nghiên cứu mối liên quan giữa tải lượng vi rút với một số biểu hiện lâm sàng và xét nghiệm chức năng gan ở bệnh nhân viêm gan vi rút $B$ man tính", Y hoc thức hành. 843, 62-65.

2. Nguyến Đức Cường và Đồ Quốc Tiệp (2017), "Thực trang nhiếm vi rút viêm gan $B$ trong cộng đồng dân cư tỉnh Quảng Bình năm 2017", Tạp chi thông tin khoa học và công nghệ Quảng Bình. 4, 76-82.

3. Nguyễn Văn Dũng (2015), Đặc điểm dịch tễ, sinh hoc phân tứ, lâm sàng, cân lâm sàng và yếu tố ảnh hưởng điếu trị đến hiệu quả điều trị viêm gan vi rút $\mathrm{B}$ mạn bằng thuốc kháng vi rút, Luận án Tiến sỹ, Viên Về sinh Dich tễ Trung ương, Hà Nôii.

4. Đình Văn Huy (2012), Đánh giá kết quả điêuu trị của tenofovir trên bênh nhân viêm gan vi rút $B$ mạn tại Bệnh viện Bệnh Nhiệt đới Trung ương, Luận vằn Thạc sỹ $Y$ học, Học viện Quân $y$, Hà Nội.

5. Ngô Viết Lộc (2012), Nghiên cứu tình hình nhiềm vi rút viêm gan $B$ và đánh giá kết quả can thiêp công đồng taii môt số xã, phường tỉnh Thừa Thiển Huêe, Luận án Tiến sỹ Y hoc, Đại học Y - Dược Huế

6. Đố Thị Lê Quyên (2015), Đánh giá đáp ứng điều trị với Entecavir ở bệnh nhân viêm gan vi rút $B$ man tính hoạt động có $\mathrm{HBeAg}$ dương tính và âm tính, Luân văn Thac sỹ Y hoc, Hoc viên Quân y, Hà Nội.

7. Nguyền Hữu Quyên (2015), Nghiên cứu nồng đô HBSAg, tải lương vi rút và hoạt độ ALT huyết tương ở các thể lầm sàng nhiễm vi rút viêm

8. World Health Organization (WHO) (2012) Prevention and control of viral hepatitis infection: framework for global action., WHO, Geneva.

\section{YẾU TỐ LIÊN QUAN VỚI SỰ TUÂN THỦ ĐIỀU TRI Ở NGƯờI BỆNH TĂNG HUYẾT ÁP ĐIỀU TRI NGOẠI TRÚ}

\section{TÓM TẮT}

Cơ sở nghiên cứu: sự tuân thủ điều trị quyết định sự thành công của việc điều trị bệnh tăng huyết áp. Mục tiêu: tìm hiểu một số yếu tổ liên quan với tình trạng tuân thủ điêu trị ở người bệnh tăng huyết áp ngoại trú. Đối tượng và phương pháp: Nghiên cứu được thực hiện tại phòng khám ngoại trú tuyến cơ sở. Các yếu tố liên quan được đánh giá bao gồm tuổi, giới, trình độ học vấn, số thuốc sử dụng, bệnh

\footnotetext{
${ }^{1}$ Trung tâm Y tế - Môi trường lao động Công thương ²Bênh viện Lão khoa Trung ương

${ }^{3}$ Trường Đại học Y Hà Nội

${ }^{4}$ Trung tâm Chống độc - Bệnh viện Bạch Mai

Chịu trách nhiệm chính: Nguyễn Trung Anh

Email: trunganhvlk@gmail.com

Ngày nhận bài: 5.01.2021

Ngày phản biện khoa học: 3.3.2021

Ngày duyệt bài: 12.3.2021
}

\author{
Đào Văn Cường1, Nguyễn Ngọc Tâm ${ }^{2,3}$, \\ Đặng Thị Xuân ${ }^{4}$, Nguyễn Trung Anh ${ }^{2,3}$
}

mắc kèm. Mối liên quan với đạt huyết áp mục tiêu được đánh giá. Kết quả: Các nhóm tuổi trên có sư đồng đều về tuân thủ thuốc: nhóm tuổi từ 40-60 tuổi là $72,6 \%$, nhóm tuổi $61-75$ tuổi là $71,3 \%$, nhóm tuối $\geq 75$ tuổi là $69,2 \%$. Tuân thủ tốt ở nhóm điêuu trị THA đơn độc là $71,4 \%$, tuân thủ tốt ở nhóm mắc kèm thêm 01 bênh là $72,5 \%$, tuân thủ tốt ở nhóm mắc kèm thêm 02 bệnh là $66,7 \%$. Tỷ lệ bệnh nhân tuân thủ tốt đạt mục tiêu huyết áp là $53,5 \%$, tuân thủ tốt không đạt mục tiêu 18,1\%. Kết luận: Một số yếu tố liên quan tới sự tuân thủ thuốc là số thuốc huyết áp phải sử dụng, số bệnh mắc kèm theo. Tuân thủ thuốc tốt liên quan tới đạt muc tiêu điều trị tốt hơn.

Tư khóa: tăng hyểt áp,tuân thủ, yếu tố liên quan.

\section{SUMMARY}

RELATED FACTORS WITH MEDICATION ADHERENCE OF HYPERTENSIVE OUTPATIENTS

Background: The medication adherence decide the effect on hypertensive treatment. Objectives: To 